\title{
INTERVENSI SOSIAL TERHADAP PENGEMBANGAN MASYARAKAT LOKAL DI DAERAH TRANSMIGRASI DESA TOPOYO
}

\author{
Azhary Adhyn Achmad ${ }^{1}$, R. Nunung Nurwati ${ }^{2}$, Nandang Mulyana \\ ${ }^{1}$ Progrm Studi Ilmu Kesejahtraan Sosial \\ Universitas Padjadjaran \\ Email: azharyaa2@gmail.com \\ ${ }^{2}$ Progrm Studi Ilmu Kesejahtraan Sosial \\ Universitas Padjadjaran \\ Email: nngnurwati@yahoo.co.id \\ ${ }^{3}$ Progrm Studi Ilmu Kesejahtraan Sosial \\ Universitas Padjadjaran \\ Email: mulyananandang@yahoo.com
}

\begin{abstract}
Abstrak
Pengembangan masyarakat lokal di daerah transmigrasi Desa Topoyo bertujuan untuk mendorong kemampuan dan kemandirian masyarakat lokal dalam mengelola dan memanfaatkan sumberdaya lokal di daerah transmigrasi agar dapat seiring dan kerjasama dengan transmigran dalam meningkatkan kualitas hidup masyarakat lokal setempat. Intervensi Sosial pada level komunitas lokal dapat menjadi salah satu metode yang digunakan untuk upaya pengembangan masyarakat lokal melalui serangkaian cara dan strategi yang dilakukan oleh pelaku intervensi atas dasar adanya kemauan dan komitmen untuk membantu bagi kemajuan dan peningkatan kualitas hidup masyarakat lokal di sekitar kawasan transmigrasi Desa Topoyo. Penelitian ini menggunakan pendekatan kualitatif yang menghasilkan data deskriptif mengenai proses pengembangan masyarakat lokal di daerah transmigrasi Desa Topoyo. Teknik pengumpulan data melalui observasi langsung, wawancara dan studi dokumen. Informan ditentukan secara purposif berdasarkan karakteristik dan dan kesesuaian data yang dibutuhkan. Hasil penelitian menunjukkan bahwa melalui Intervensi Sosial pada level komunitas lokal dapat mendorong dan membangkitkan kemampuan serta kemandirian masyarakat lokal di daerah transmigrasi Desa Topoyo dalam meningkatkan kualitas dan taraf hidupnya.
\end{abstract}

Kata Kunci: Pengembangan masyarakat lokal, intervensi sosial, peningkatan taraf hidup.

\section{SOCIAL INTERVENTION OF LOCAL COMMUNITY DEVELOPMENT IN THE TOPOYO VILLAGE TRANSMIGRATION AREA}

\begin{abstract}
The development of local communities in the transmigration area of Topoyo Village aims to encourage the ability and independence of local communities in managing and utilizing local resources in the transmigration area so that they can be in tandem with and cooperate with transmigran in improving the quality of life of the local community. Social Interventions at the local community level can be one of the methods used for efforts to develop local communities through a series of ways and strategies carried out by interventions on the basis of the willingness and commitment to help progress and improve the quality of life of local communities around the transmigration area of Topoyo Village. This study uses a qualitative approach that produces descriptive data on the process of developing local communities in the transmigration area of Topoyo Village. Data collection techniques through direct observation,
\end{abstract}


interviews and document studies. Informants are determined purposively based on the characteristics and suitability of the required data. The results showed that through Social Interventions at the local community level can encourage and awaken the ability and independence of local communities in the transmigration area of Topoyo Village in improving their quality and standard of living.

Keywords: Local community development, social intervention, improvement of living standard.

\section{PENDAHULUAN}

Hakikat

Pengembangan

Masyarakat pada dasarnya adalah untuk meningkatkan

kesejahteraan

masyarakat pada suatu daerah yang kondisinya masih tertinggal dan belum mampu mengatasi hambatan-hambatan sosial dalam upaya mengembangkan diri untuk menjamin kelangsungan hidup masyarakat secara mandiri dan terus menerus. Sebagaimana halnya dengan masyarakat lokal yang merupakan komunitas penduduk lokal suatu daerah yang hidup berdampingan dengan masyarakat pendatang, namun kondisinya cenderung masih tertinggal dan membutuhkan bantuan dari beberapa pihak untuk merubah kondisi hidup masyarakat lokal menjadi lebih baik dan meningkat.

Pengembangan Masyarakat merupakan suatu model intervensi yang sangat memperhatikan aspek manusia serta pemberdayaan masyarakat, dimana di dalamnya kental terasa adanya unsur pendidikan dalam upaya mengubah suatu komunitas. Partisipasi masyarakat dalam proses intervensi pengembangan masyarakat menjadi salah satu kunci terwujudnya peningkatan kondisi sosial ekonomi masyarakat. Sebagai sebuah metode atau pendekatan yang cukup efektif, pengembangan masyarakat menekankan adanya proses pemberdayaan, partisipasi, dan peranan langsung warga komunitas dalam proses pembangunan di tingkat komunitas dan antar komunitas (Adi, 2012)

Pengembangan masyarakat sangatlah di butuhkan oleh banyak pihak karena secara langsung dapat menyelesaikan masalah sosial yang seakan-akan tidak pernah selesai di kalangan masyarakat. Pengembangan masyarakat memiliki fokus terhadap upaya menolong anggota masyarakat yang memiliki kesamaan minat untuk bekerja sama, mengidentifikasi kebutuhan bersama dan kemudian melakukan kegiatan bersama untuk memenuhi kebutuhan tersebut. Pengembangan masyarakat juga pada umumnya diartikan sebagai bentuk pelayanan yang menggunakan pendekatan-pendekatan yang lebih condong kepada upaya pemberdayaan masyarakat dengan memperhatikan sisi keberagaman masyarakat target pemberdayaan dan pengembangan. Dengan demikian pengembangan masyarakat dapat diartikan sebagai suatu metode yang memungkinkan orang dapat meningkatkan kualitas hidupnya dan mampu memperbesar pengaruh dan peluang terhadap proses- 
proses yang mempengaruhi kehidupannya (Heeren, 1979).

Dalam upaya Pengembangan masyarakat terdapat model-model intervensi yang disesuaikan dengan kondisi dan kebutuhan masyarakat target intervensi sehingga secara tepat masyarakat bisa berkembang dan meningkatkan taraf hidupnya. Dalam konteks pendekatan masyarakat lokal, intervensi sosial merupakan suatu upaya peningkatkan kapasitas, mengintegrasikan dan membantu komunitas lokal di suatu daerah agar dapat lebih mandiri, sehingga mampu menyelesaikan masalahnya sendiri. Pendekatan ini mengasumsikan adanya hubungan yang tidak serasi sehingga dianggap penting untuk melibatkan seluruh warga masyarakat dalam mencapai kesepakatan melalui komunikasi dan diskusi. Pelaku intervensi berperan sebagai katalisator yang mendorong pembentukan kelompok kerja untuk mencari penyelesaian masalah yang memadukan kegiatan-kegiatan lokal dengan analisis kelembagaan dan kebijakan sosial secara terintegrasi.

Upaya

pengembangan

masyarakat lokal menjadi prioritas yang dapat dilakukan oleh beberapa pihak, baik dari luar (external) maupun dari dalam masyarakat itu sendiri (internal), yang memiliki kepedulian, kemauan dan komitmen untuk membantu proses perubahan kondisi kehidupan masyarakat lokal. Fokus utama pengembangan masyarakat lokal ini adalah untuk menolong komunitas atau masyarakat lokal yang memiliki kesamaan kondisi sosial dan mau bekerjasama untuk mengidentifikasi kebutuhan bersama kemudian melakukan kegiatan bersama untuk memenuhi kebutuhan tersebut.

Salah satu pihak atau unsur masyarakat yang dapat membantu dalam upaya pengembangan masyarakat lokal di daerah transmigrasi adalah Transmigran yang telah berhasil dan sukses di daerah transmigrasi yang memiliki pengalaman, keuletan, pengetahuan dan keterampilan serta daya juang dan semangat kerja yang kuat yang dapat ditularkan kepada masyarakat lokal. Di samping itu, antara transmigran dan masyarakat lokal juga memiliki kedekatan secara geografis yaitu berada dalam satu wilayah yang sama dan memiliki hubungan interkasi sosial yang baik yang telah dibangun sejak awal transmigran datang ke daerah tujuan transmigrasi (Najiyati, 2008).

Pola pengembangan masyarakat yang dapat dilakukan oleh transmigran dalam membantu masyarakat lokal yang tinggal di sekitar kawasan transmigrasi untuk meningkatkan kualitas hidupnya adalah melalui penerapan metode Intervensi Sosial pada level komunitas/masyarakat lokal. Dimana intervensi sosial ini merupakan suatu cara atau strategi dalam memberikan bantuan kepada masyarkat (individu, kelompok dan komunitas), untuk meningkatkan kesejahteraannya melalui upaya pengaktifan kembali fungsi sosialnya. Maksudnya setiap masyarakat 
harus mampu berperan sesuai dengan statusnya di dalam masyarakat (Rahardjo, 2017) .

Intervensi sosial merupakan perubahan yang terencana yang dilakukan oleh pelaku perubahan (change agent) terhadap berbagai sasaran perubahan (target of change) yang terdiri dari individu, keluarga, dan kelompok kecil (level mikro), komunitas dan organisasi (level mezzo) dan masyarakat yang lebih luas, baik ditingkat kabupaten/kota, provinsi, negara, maupun tingkat global (level makro) (Adi, 2012).

Dalam pengertian yang lain juga dijelaskan bahwa Intervensi sosial merupakan suatu tindakan spesifik oleh seorang pelaku intervensi dalam kaitannya dengan sistem atau proses manusia dalam rangka menimbulkan perubahan (Johnson, 2001). lebih lanjut Johnson mengungkapkan bahwa melalui intervensi sosial, hambatan sosial yang dihadapi kelompok sasaran perubahan akan diatasi. Dengan kata lain, intervensi sosial berupaya memperkecil jarak antara harapan lingkungan dengan kondisi kenyataan klien (Johnson, 2001).

Kesimpulan mengenai definisi Intervensi Sosial adalah suatu metode perubahan sosial yang dilakukan untuk meningkatkan kesejahteraan masyarakat yang menjadi sasaran intervensi dalam melakukan perubahan sosial yang diinginkan oleh pelaku perubahan.

Tujuan utama intervensi sosial adalah membantu masyarakat untuk memperoleh kembali keberfungsian sosialnya, meningkatkan kemampuan mengatasi masalah yang dihadapi dengan teknik penyelesaian masalah yang lebih baik serta dapat menjalankan peran barunya sesuai dengan perkembangan yang dialami agar hambatan sosial yang dihadapi tidak terulang lagi (Adi, 2012).

Adapun dalam penelitian ini fokus mengkaji mengenai pengembangan masyarakat dengan menggunakan pendekatan Intervensi Sosial, dimana unit intervensinya pada level komunitas/masyarakat lokal di sekitar kawasan transmigrasi, dengan tujuan untuk mendorong dan mengupayakan terjadinya perubahan kearah yang positif bagi kemajuan dan kemandirian masyarakat lokal yang tinggal sekitar kawasan transmigrasi.

\section{METODE}

Penelitian ini dilakukan di daerah kawasan transmigrasi Desa Topoyo, dimana terdapat masyarakat lokal dan transmigran yang telah lama hidup berdampingan dengan aman tanpa terjadi konflik yang menjadi subjek dalam penelitian ini.

Rancangan penelitian ini menggunakan pendekatan kualitatif yang bertujuan untuk menghasilkan data deskriptif mengenai proses pengembangan masyarakat lokal di daerah transmigrasi desa Topoyo. Tujuan dari pemilihan metode kualitatif adalah untuk memahami masalahmasalah sosial dengan menciptakan gambaran menyeluruh dan kompleks 
yang disajikan dengan kata-kata, melaporkan pandangan terinci yang diperoleh dari para sumber informasi, serta dilakukan dalam latar (setting) yang alamiah (Creswell, 2012).

Penelitian ini diawali dengan mengidentifikasi masalah yang dialami oleh masyarakat lokal di daerah transmigrasi Desa Topoyo, selanjutnya melakukan peninjauan dan studi literatur terhadap teori dan konsep yang relevan dengan permasalahan yang akan diteliti, berikutnya mengadakan observasi awal yang dilanjutkan dengan penelitian langsung di lapangan.

Informan dalam penelitian ini ditentukan secara purposif berdasarkan karakteristik dan kesesuaian dengan data yang diperlukan, yaitu mereka yang terlibat langsung dan memiliki hubungan dengan kehidupan masyarakat lokal di Desa Topoyo.

Teknik pengumpulan data dalam penelitian ini dilakukan melalui observasi langsung, wawancara mendalam (deep interview) dan studi dokumen. Melalui ketiga teknik tersebut diharapkan dapat diperoleh data yang jelas dan rinci mengenai proses pengembangan masyarakat lokal di daerah transmigrasi Desa Topoyo. Sedangkan pengolahan dan analisis data mengacu pada pendapat bahwa aktivitas dalam analisis data kualitatif dilakukan secara interaktif dan berlangsung secara terus menerus sampai tuntas hingga datanya jenuh. Adapun metode pengolahan dan analisis data tersebut terdiri dari empat hal, meliputi pengumpulan data, reduksi, penyajian, dan penarikan kesimpulan (Miles, 2009).

\section{HASIL DAN PEMBAHASAN}

\section{A. Pengembangan Masyarakat Lokal di Desa Topoyo}

Desa Topoyo merupakan salah satu daerah yang menjadi tujuan penempatan transmigran di Kabupaten Mamuju Tengah, dengan masuknya transmigran di daerah ini berdampak terhadap terjadinya perubahan dalam kehidupan masyarakat, utamanya pada aspek sosial, ekonomi dan budaya. Masyarakat lokal di Desa Topoyo cenderung masih tertinggal jika dibandingkan dengan masyarakat transmigran yang kehidupannya telah meningkat setelah beberapa tahun menetap di daerah transmigrasi dengan kemampuan dan keuletan mengelola sumberdaya lokal di daerah transmigrasi utamanya dalam bidang pertanian dan perkebunan.

Pengembangan masyarakat lokal di daerah transmigrasi Desa Topoyo merupakan suatu bentuk perhatian dan kepedulian pada masyarakat lokal di daerah ini, dimana upaya pengembangan masyarakat bertujuan untuk mensejajarkan kondisi sosial, ekonomi dan keadilan kepada masyarakat lokal untuk mencegah kecemburuan sosial dan yang paling utama adalah sebagai upaya mengembangkan kapasitas diri masyarakat lokal agar dapat bangkit dari ketertinggalan, mampu mengelola dan memanfaatkan lahan usaha secara mandiri dan profesional, melalui 
kerjasama dan partisipasi warga transmigran untuk membantu, memotivasi dan memberdayakan masyarakat lokal melalui pembinaan dan pelatihan bercocok tanam yang tepat agar masyarakat lokal dapat berhasil sebagaimana yang telah dicapai oleh mayoritas warga transmigran di daerah penempatan dan pemukiman Desa Topoyo.

Pengembangan masyarakat lokal merupakan suatu proses yang ditujukan untuk menciptakan kemajuan sosial dan ekonomi masyarakat melalui pertisipasi aktif serta inisiatif dari masyarakat sendiri. Anggota masyarakat bukan sebagai klien yang bermasalah melainkan sebagai masyarakat yang unik dan memiliki potensi yang belum sepenuhnya dikembangkan (Rothman, Jack, Erlich, John L. ; Tropman, 2001).

$$
\text { Proses pengembangan }
$$

masyarakat lokal di Desa Topoyo dilakukan oleh transmigran sukses sebagai pelaku intervensi melalui pertisipasi aktif dari masyarakat lokal sendiri sebagai target intervensi. Partisi disini meliputi keaktifan dan keikutsertaan secara langsung oleh setiap individu dari masyarakat lokal untuk mengambil bagian dalam kegiatan-kegiatan pengembangan masyarakat lokal yang telah direncanakan dan disusun bersama oleh transmigran dan masyarakat lokal sendiri.

Setiap agenda dan kegiatan pengembangan masyarakat lokal di Desa Topoyo disesuaikan dengan kebutuhan masyarakat itu sendiri. Hal tersebut didasarkan pada aktivitas dan potensi yang dimiliki oleh masyarakat lokal. Misalnya pelatihan dan pembinaan dalam bidang pertanian dan perkebunan yang merupakan aktivitas dan mata pencaharian utama masyarakat lokal di Desa Topoyo, di samping itu ada juga beberapa masyarakat lokal yang memiliki potensi di bidang kewirausahaan dimana semua bidang keahlian tersebut telah digeluti oleh transmigran dan membuahkan hasil yang baik dan memuaskan sehingga mampu mengangkat kesejahteraan transmigran.

Bentuk upaya pengembangan masyarakat lokal di daerah transmigrasi Desa Topoyo dilakukan melalui intervensi langsung kepada masyarakat lokal dengan memperhatikan kebutuhan dan aktivitas masyarakat lokal. Kebutuhan akan upaya pengembangan masyarakat lokal di Desa Topoyo semua berkaitan dengan bidang pertanian dan perkebunan yang linier dan sesuai dengan keahlian serta profesionaliltas yang dimiliki oleh transmigran sebagai pelaku intervensi dalam pengembangan masyarakat lokal tersebut, sehingga dalam pelaksanaan intervensi berjalan dengan baik dan lancar serta membuahkan hasil yang maksimal karena adanya pemenuhan kebutuhan berupa skill, pengetahuan dan nilai-nilai positif yang sangat dibutuhkan oleh masyarakat lokal dalam mengembangkan potensi diri dan lingkungannya.

Semua bentuk pengembangan masyarakat akan lebih maksimal dalam 
pelaksanaannya apabila dilakukan dalam bentuk intervensi sosial dengan terperinci dan terencana prosesnya kepada target intervensi semisal komunitas masyarakat lokal yang berada dalam suatu kawasan dan wilayah yang sama. Hal ini akan lebih muda dilakukan oleh pelaku intervensi karena masyarakat lokal cenderung memiliki hambatan dan permasalahan yang sama dalam suatu wilayah, sehingga proses assesment dan penanganan masalah dalam pengembangan masyarakat akan lebih efektif dan lebih cepat dalam proses perubahan masyarakat lokal.

Sebagaimana pelaksanaan pengembangan masyarakat lokal di darah transmigrasi Desa Topoyo, semua masyarakat lokal yang memiliki permasalahan dan hambatan yang sama mudah untuk di organisir oleh pelaku intervensi karena berada dalam suatu wilayah yang sama. Pelaku intervensi sosial, dalam hal ini transmigran sukses langsung menerapkan pola intervensi dengan membentuk kelompokkelompok pelatihan dan pembinaan sumber daya profesional dalam bidang pertanian dan perkebunan.

Dengan adanya beberapa faktor yang mempengaruhi kelancaran dan keberhasilan dalam proses pengembangan masyarakat lokal di daerah transmigrasi Desa Topoyo, saat ini dapat terlihat adanya kemajuan dan perkembangan yang dialami masyarakat lokal. Peneliti melihat dan memperoleh data serta informasi secara langsung bahwa saat ini di Desa Topoyo semua lahan pertanian dan perkebunan di kelola atau digarap dengan proses yang modern dengan keahlian dan profesionalitas yang tinggi, serta komoditi yang ditanam juga lebih beragam dan cocok untuk lokasi pertanian di daerah transmigrasi Desa Topoyo, serta saat ini tidak ada lagi pola bercocok tanam dengan cara tradisional seperti berpindah-pindah tempat dan komoditi tanam yang monoton dan tidak produktif yang menjadi ciri khas masyarakat lokal sebelum masuknya transmigran di daerah ini. Menjadi hal yang positif dengan masuknya transmigran dan membawa banyak pengaruh dan hal positif untuk mendukung pengembangan dan kemajuan masyarakat lokal di daerah transmigrasi Desa Topoyo.

Upaya pengembangan masyarakat dengan berbagai strategi dan cara yang diimplementasikan dalam bentuk kegiatan pembinaan dan sharing skill berupa pengetahuan, pengalaman dan motivasi/dorongan, kesemuanya ditujukan untuk menciptakan kemajuan, kemandirian dan peningkatan taraf hidup masyarakat lokal di daerah yang sebelumnya tertinggal seperti daerah transmigrasi Desa Topoyo.

\section{B. Pelaksanaan Intervensi Sosial Terhadap Masyarakat Lokal}

Intervensi Sosial menjadi metode yang efektif untuk mendorong perubahan sosial dalam rangka pengembangan masyarakat yang difokuskan untuk meningkatkan kesejahteraan masyarakat yang menjadi sasaran intervensi dalam melakukan 
perubahan sosial yang diinginkan oleh pelaku intervensi

Bentuk Intervensi Sosial yang dilakukan transmigran terhadap masyarakat lokal di daerah transmigrasi ialah dengan cara membagikan atau menularkan pengetahuan (knowledge), keterampilan (skill) dan nilai-nilai kebaikan (value) dalam pengelolaan dan pemanfaatan sumber daya lokal yang ada, agar dapat di adopsi dan diterapkan dengan baik dan sungguhsungguh, sehingga mampu mengangkat kualitas dan taraf hidup masyarakat lokal di sekitar kawasan transmigrasi Desa Topoyo.

Berikut disajikan dalam gambar 1. Skema penerapan Intervensi yang dilakukan oleh Transmigran sukses sebagai pelaku Intervensi terhadap upaya pengembangan masyarakat lokal di daerah transmigrasi Desa Topoyo

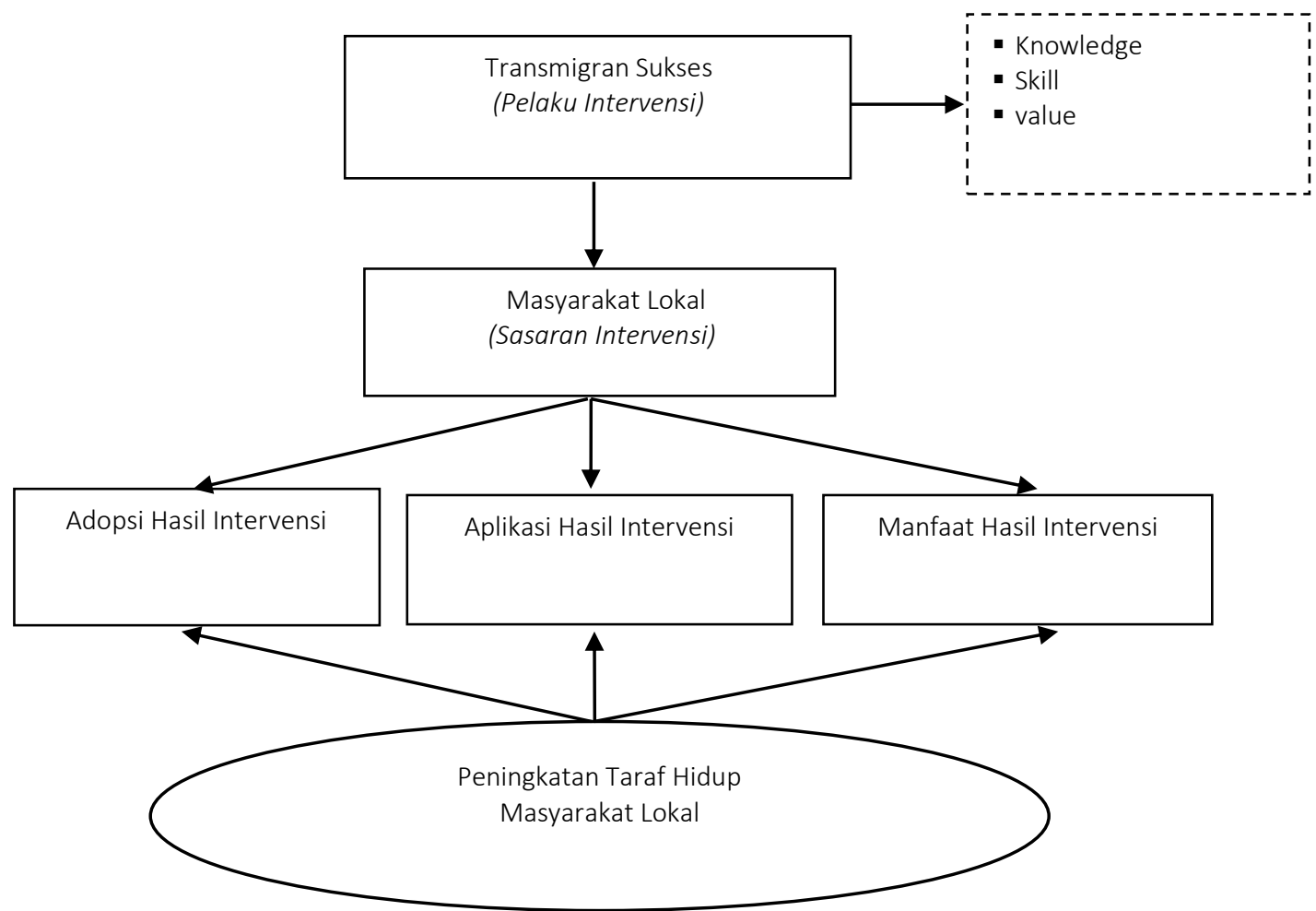

Gambar 1. Skema penerapan Intervensi Sumber: Olahan Peneliti, 2019

Dari skema diatas dapat digambarkan mengenai proses Intervensi sosial yang dilakukan oleh Transmigran kepada masyarakat lokal untuk membantu dan mengaktifkan fungsi sosial masyarakat lokal dalam meningkatkan taraf hidup dan kesejahteraan masyarakat lokal.
Adapun bentuk dan strategi Intervensi Sosial yang dilakukan oleh Transmigran dalam pengembangan masyarakat lokal di Desa Topoyo yaitu:

1. Pertama-tama transmigran melakukan assesment terhadap permasalahan yang dihadapi masyarakat lokal sehingga tidak 
mampu mengembangkan diri dalam mengelola sumberdaya lokal daerah dengan baik. Dari hasil assesment diidentifikasi bahwa permasalahan dan hambatan yang dialami masyarakat lokal di Desa Topoyo adalah kurangnya SDM berupa pengetahuan dan keterampilan dalam mengelola dan memanfaatkan potensi lokal di daerah ini sehingga mengakibatkan terjadinya stagnasi dalam peningkatan dan pengembangan diri masyarakat lokal yang berpengaruh pada ketidakmampuan dalam pemenuhan kebutuhan dasar.

2. Setelah diketahui permasalahan yang dihadapi masyarakat lokal melalui proses assesment, transmigran sebagai pelaku intervensi menyusun langkah-langkah dan persiapan kegiatan untuk membantu masyarakat lokal dalam mengelola sumberdaya lokal di daerah transmigrasi. Langkah-langkah dan persiapan yang dilakukan transmigran di Desa Topoyo ini memperhatikan kebutuhan dan pemecahan masalah yang tepat bagi masyarakat lokal dan dalam pelaksanaan intervensi sosial tidak memaksakan keinginan dan ambisi perubahan kepada masyarakat lokal.

3. Setelah assesmen dan langkahlangkah persiapan intervensi dilakukan, transmigran sebagai pelaku intervensi melakukan kegiatan dalam bentuk pelatihan dan pembinaan kepada masyarakat lokal berupa kemampuan mengelola dan menggarap lahan pertanian dan perkebunan secara efektif. Dalam praktik ini transmigran di daerah transmigrasi Desa Topoyo membuat kelompok-kelompok pelatihan yang terdiri dari 5 sampai 7 orang masyarakat lokal untuk dilatih dan diberi pengetahuan dan keterampilan bercocok tanam dengan baik. Pada kesempatan tersebut transmigran juga membagikan sampel bibit tanaman baru dan potensial seperti bibit kakao, kedelai, padi, jagung dan jeruk untuk ditanam dan dikembangkan oleh masyarakat lokal di lahan pertanian dan perkebunannya.

4. Setelah proses dan tahapan intervensi sosial telah dilakukan oleh transmigran kepada masyarakat lokal di Desa Topoyo, selanjutnya transmigran terus melakukan pendampingan dan evaluasi terhadap perkembangan dan kemajuan yang dialami masyarakat lokal sampai betul-betul mampu mengadopsi dan menerima setiap pengetahuan, keterampilan dan nilainilai kebaikan yang telah dibagikan oleh transmigran sebagai pelaku intervensi kepada masyarakat lokal di daerah transmigrasi Desa Topoyo.

Inti dari penerapan metode intervensi sosial dalam pengembangan masyarakat lokal adalah diterimanya hasil intervensi untuk diadopsi dengan baik oleh masyarakat lokal, kemudian diaplikasikan atau dilaksanakan apa yang telah diterima dalam proses 
intervensi tadi, selanjutnya sebagai hasil akhir adalah kebermanfaatan yang diperoleh dari hasil intervensi sosial yang dilakukan oleh transmigran sukses sebagai pelaku intervensi kepada masyarakat lokal target intervensi.

\section{Peningkatan Taraf Hidup Masyarakat Lokal}

Hasil penelitian ini menerangkan bahwa melalui penerapan strategi dan metode intervensi sosial dalam upaya pengembangan masyarakat lokal di daerah transmigrasi Desa Topoyo, mampu membawa perubahan yang mengarah pada peningkatan kualitas dan taraf hidup masyarakat lokal di Desa Topoyo. Kondisi tersebut ditandai dengan meningkatnya kesejahteraan masyarakat lokal di daerah transmigrasi Desa Topoyo ditinjau dari beberapa aspek, utamanya di bidang sosial dan ekonomi masyarakat lokal.

Aspek sosial ekonomi merupakan bagian dari indikator utama untuk melihat kondisi kesejahtraan masyarakat, termasuk masyarakat lokal di daerah transmigrasi Desa Topoyo. Kedua aspek ini tidak dapat dipisahkan dan saling keterkaitan di dalamnya. Apabila kondisi perekonomian masyarakat membaik maka akan berpengaruh pula terhadap kondisi sosial masyarakat tersebut.

Sosial ekonomi merupakan segala sesuatu yang saling berkaitan dengan pemenuhan kebutuhan yang ada di masyarakat atau lebih umumnya terkait dengan kesejahteraan masyarakat untuk melihat kondisi sosial ekonominya (Junaidi ; Hardiani, 2009).

$\begin{array}{llr}\text { Kondisi } & \text { sosial ekonomi } \\ \text { masyarakat lokal di } & \text { daerah } \\ \text { transmigrasi } & \text { Desa Topoyo yang }\end{array}$
diperoleh dari hasil penelitian meliputi kondisi sebelum masuknya transmigran dan setelah masuknya transmigran dengan berbagai pengaruh dan kebiasaan yang ditularkan. Melalui penelitian yang dilakukan dengan mengumpulkan data dan informasi dari sumber yang jelas, menerangkan bahwa sebelum masuknya transmigran, daerah ini sangat tertinggal dan pembangunan daerah hampir tidak ada, serta masyarakatnya yang tidak dapat mengembangkan diri untuk meningkatkan taraf hidupnya. Setelah masuk masuknya transmigran ke daerah ini perubahan sangat terasa dan terlihat adanya peningkatan kondisi kehidupan masyarakat lokal.

Peran transmigran dalam bentuk intervensi sosial yang menularkan banyak manfaat dan nilainilai kebaikan dalam rangka pengembangan masyarakat lokal menjadi nilai tambah dan point positif dari program transmigrasi yang dicanangkan pemerintah.

Peningkatan taraf hidup masyarakat lokal di daerah transmigrasi Desa Topoyo khususnya dalam bidang sosial ekonomi yang sangat terasa adalah adanya hubungan sosial yang baik, harmonis dan terbuka antara transmigran dan masyarakat lokal. Hubungan sosial yang baik ini ikut mempengaruhi kondisi ekonomi 
masyarakat, dimana muncul kepedulian dan empati dari transmigran ketika melihat kondisi ekonomi masyarakat lokal masih tertinggal dan cenderung tidak ada peningkatan, sehingga transmigran dengan berbagai pengetahuan dan skill yang dimiliki dalam mengelola dan memanfaatkan potensi lokal daerah, berusaha menularkan dan membagikan pengetahuan, skill, pengalaman dan semangat kerja tersebut kepada masyarakat lokal untuk dapat di adopsi dan diterapkan dalam pemanfaatan potensi sumberdaya lokal khususnya dalam bidang pertanian dan perkebunan.

Melalui penerapan intervensi sosial kepada masyarakat lokal, sampai dengan saat ini taraf hidup dan kesejahtraan masyarakat lokal di darah transmigrasi Desa Topoyo mengalami peningkatan dan kemajuan. Diantaranya, pendapatan masyarakat meningkat, mata pencaharian jelas dan menjanjikan, potensi lokal daerah mampu dikelola dengan baik dalam jangka waktu yang panjang, hubungan atau interaksi sosial terjalin dan terjaga dengan baik antara transmigran dan masyarakat lokal, serta peran masyarakat lokal dan transmigran dalam pembangunan daerah dapat terlihat dan dirasakan manfaatnya.

\section{KESIMPULAN}

Pendekatan model Intervensi Sosial dalam Pengembangan Masyarakat Lokal merupakan suatu metode intervensi yang sangat memperhatikan aspek manusia serta aspek pemberdayaan masyarakat lokal. Pengembangan masyarakat lokal di daerah transmigrasi Desa Topoyo merupakan suatu upaya untuk mendorong kemampuan dan kemandirian masyarakat lokal dalam mengelola dan memanfaatkan sumberdaya lokal di daerah transmigrasi.

Transmigran sukses dapat menjadi pelaku intervensi untuk melakukan pembinaan dan pelatihan sebagai upaya mengubah kondisi sosial masyarakat lokal menjadi lebih baik dan sejahtera. Bentuk intervensi yang dilakukan transmigran terhadap masyarakat lokal di daerah transmigrasi ialah dengan menularkan pengetahuan (knowledge), keterampilan (skill) dan nilai-nilai kebaikan (value).

Dengan penerapan model intervensi sosial dalam pengembangan masyarakat lokal di daerah transmigrasi Desa Topoyo, terjadi perubahan kondisi kehidupan masyarakat lokal, utamanya dalam bidang sosial dan ekonomi.

\section{DAFTAR PUSTAKA}

Adi, I. R. (2012). Intervensi Komunitas: Pengembangan Masyarakat Sebagai Upaya Pengembangan Masyarakat (Revisi). Jakarta: Raja Grafindo Persada.

Creswell, J. W. (2012). Research Design: Pendekatan Penelitian Kualitatif, Kuantitatif, dan Mixed Method. Yogyakarta: Pustaka Pelajar.

Heeren, H. J. (1979). Transmigrasi di Indonesia. Jakarta: Gramedia Pustaka. 
Johnson, L. C. (2001). Praktek Pekerjaan Sosial (Suatu Pendekatan Generalist). Bandung: STKS.

Junaidi; Hardiani. (2009). Dasar-Dasar Teori Ekonomi Kependudukan. Jakarta: Hamada Prima.

Miles, M. B. ; A. M. H. (2009). Analisis Data Kualitatif. Jakarta: UI Press.

Najiyati, S. (2008). Transmigrasi dan Pengembangan Masyarakat Desa Sekitar. Jakarta: Bangkit Daya Insana. Jakarta: Bangkit Jaya Insana.

Rahardjo. (2017). Pengantar Sosiologi Pedesaan dan Pertanian (5th ed.). Yogyakarta: UGM Press.

Rothman, Jack, Erlich, John L. ; Tropman, J. (2001). Tactics of Community Intervention. Bellmont: CA: Brooks/Cole Thomson Learning. 